\title{
Effect of Different Inoculum Densities of S. rolfsii on Seed Germination, Seedling Growth Parameters and Disease Incidence
}

\author{
B. Raghavendra*, T. Srinivas and B. Padmodaya \\ Department of Plant Pathology, S.V. Agricultural College, Tirupati-517502, \\ Andhra Pradesh, India \\ *Corresponding author
}

A B S T R A C T

\begin{tabular}{|c|}
\hline Keywords \\
\hline $\begin{array}{l}\text { Root length, Germination } \\
\text { percentage, Shoot length } \\
\text { and Inoculum density }\end{array}$ \\
\hline Article Info \\
\hline $\begin{array}{l}\text { Accepted: } \\
\text { 04 July } 2018 \\
\text { Available Online: } \\
\text { 10 August } 2018\end{array}$ \\
\hline
\end{tabular}

In the present investigation effect of different inoculum densities of $S$. rolfsii on the development of stem rot of groundnut was assessed using soil infestation method in pot culture under green house and highest germination $(45.83)$, root length $(12.37 \mathrm{~cm})$ and shoot length $(15.16 \mathrm{~cm})$ was observed at 1 per cent inoculum level. Germination percentage, root length and shoot length of groundnut was gradually decreased with increase of inoculum levels from 1 to 5 per cent. Lowest germination (16.66\%), root length $(7.50 \mathrm{~cm})$, shoot length $(8.33 \mathrm{~cm})$ was observed in 5 per cent inoculum levels. Since the germination of groundnut seeds was reduced to more than 50 per cent at one per cent inoculums level, it was followed throughout the investigations.

\section{Introduction}

The groundnut production in India was 71.8 lakh tons in 2015-16. There were 9 States having groundnut production of more than 1 lakh ton viz. Gujarat, Rajasthan, Tamil Nadu, Andhra Pradesh, Karnataka, Madhya Pradesh, Maharashtra, West Bengal and Telangana in 2015-16. Gujarat was the leading producer of groundnut with 28.9 lakh tons in 2015-16 followed by Rajasthan 10.41 lakh tons and Andhra Pradesh ranks $4^{\text {th }}$ leading producer in India with 7.88 lakh tons in 2015-16. It increased by 2.95 lakh tons as compared to the groundnut production of 4.93 lakh tons in the year 2014-15. Thus, the annual growth recorded in the year 2015-16 was $59.84 \%$. (Source: Production of Groundnut from 2013-14 to 2015-16 from Ministry of Agriculture and Farmers Welfare).

The low productivity of groundnut in India was attributed to several biotic and abiotic factors. Groundnut is susceptible to wide range of microorganisms which include fungi, viruses, mycoplasma, nematodes and bacteria (Khirood and Paramjit Kaur, 2013). Among them, stem rot caused by Sclerotium rolfsii Sacc. is a major problem and is an economically important soil borne pathogen. It 
causes pod yield losses of $10-25 \%$, but under severe diseased conditions yield losses may range up to $80 \%$ (Rodriguez Kabana et al., 1975). Stem rot is a persistent soil borne disease throughout India and its incidence is increasing even at maturity stage of the groundnut crop. Though $S$. rolfsii survives both on seed and in soil, a greater threat is posed by soil borne inoculum (Kumar et al., 2013). S. rolfsii forms brownish sclerotia that can survive for long periods in the soil and retain their viability by tolerating biological and chemical degradation due to the presence of melanin in the outer membrane (Chet, 1975). S. rolfsii is a necrotrophic soil borne fungal pathogen, which has a very wide host range and distributed worldwide in warm climates (Aycock, 1966).

S. rolfsii was first reported on tomato by Rolfs (1892) and later the pathogen was named as Sclerotium rolfsii by Saccardo (1911). Higgiens (1927) worked in detail on physiology and parasitism of $S$. rolfsii. This was the first detailed and comprehensive study in USA. It is distributed in tropical and subtropical regions of the world where high temperatures prevail. The fungus has a wide host range of 500 species in about 100 families including groundnut, green bean, lima bean, onion, garden bean, pepper, potato, sweet potato, tomato and water melon (Aycock, 1966).

Stem rot of groundnut has become one of the major constraints in recent years. Management of stem rot disease is difficult because of its soil borne nature and the chemical methods are very expensive and will not be that good affect against the pathogen. In view of unsatisfactory results by chemical methods, considerable attention has been given on the other non-chemical means of plant disease control i.e., the integration of biological methods which include the use of eco-friendly bio control agents.
Kilpatrick and Merkle (1967) reported the effect of different levels of $S$. rolfsii inoculum on the foot rot of wheat and found that, 0.5 and 1.0 per cent inoculum was superior to 3,5 and 10 per cent level.

Nargund (1981) considered two per cent inoculum level as sufficient to cause considerable infection on foot rot of wheat, even though hundred per cent disease incidence was noticed at six per cent and above inoculum level.

Palakshappa et al., (1987) observed considerable foot rot infection, when betelvine were inoculated with two and three per cent inoculum and recorded 100 per cent infection at four per cent and above inoculum levels.

Harlapur (1988) reported that, two per cent inoculum was essential for infection. But, maximum infection $(100 \%)$ was noticed at inoculum level of more than four per cent in foot rot disease of wheat.

Mc Clain and Scharpf (1989) reported a positive correlation between seedling mortality of coniferous species and inoculum density, whereas plant height and weight of the surviving seedlings were negatively correlated with sclerotial density of Macrophomina phaseolina.

Uma Singh and Thapliyal (1998) reported inoculum density levels of 2.5 to $10 \mathrm{~g} \mathrm{~kg}^{-1}$ soil significantly increased the emergence of seed and seedling rot of soybean caused by $S$. rolfsii which was ranged from 36.70 to 90 per cent.

Azhar et al., (2006) observed positive correlation between disease severity and inoculum concentrations (3-20 g/560 g of soil) in collar rot of chickpea incited by $S$. rolfsii, where seedling mortality increased with an increase in inoculum load. 


\section{Materials and Methods}

Sterilized soil of one $\mathrm{kg}$ was filled in pots. Later mass multiplied $S$. rolfsii on sorghum grains was mixed with soil @ $10 \mathrm{~g}(1 \%$ inoculum), $20 \mathrm{~g}$ ( $2 \%$ inoculum), $30 \mathrm{~g}(3 \%$ inoculum), $40 \mathrm{~g}$ (4\% inoculum) and $50 \mathrm{~g} \mathrm{(5 \%}$ inoculum) kg-1 soil. Inoculums was mixed in top 2" depth of soil. Water was sprinkled to maintain moisture.

The seeds of groundnut were sown after two days of pathogen inoculation @ 8 seeds per pot and an uninoculated control was maintained. The pots were observed for seed germination and per cent seed germination was recorded. After 15 days of sowing root length, shoot length, Per cent Disease Incidence (PDI) and Per cent Disease Severity were recorded. Each treatment was replicated three times.

$$
\begin{aligned}
& \text { Per cent germination } \\
& \frac{\text { Number of seeds germinated in each treatment }}{\text { Total number of seeds planted }} \times 100 \\
& \text { Per cent disease incidence } \\
& \frac{\text { Number of diseased plants }}{\text { Total number of seeds germinated }} \times 100
\end{aligned}
$$

\section{Results and Discussion}

Studies on the effect of inoculum densities of $S$. rolfsii on the incidence of stem rot in groundnut revealed that the germination percentage of groundnut seeds was highest at one per cent inoculum density (45.83\%) i.e., 52.17 per cent reduction over control. The least germination was recorded at 5 per cent inoculum density (16.66\%), i.e., 86.21 per cent decrease over control. The results are presented in the Table 1 and Figure 1. Germination of groundnut seeds gradually decreased with increase in inoculum densities from 1 to 5 per cent and was significantly different from each other. The germination percentages recorded at different inoculum densities were in the following order.

Control $>1 \%>2 \%>3 \%>4 \%>5 \%$.

The highest root length was recorded at one percent inoculum density $(12.37 \mathrm{~cm})$ and the least at 5 percent inoculum density $(7.50 \mathrm{~cm})$. Root length of groundnut plant gradually decreased with increase of inoculum densities from 1 to 5 per cent (Plate 1). The root length at 1 per cent inoculum density was reduced to 17.69 per cent compared to control $(15.03 \mathrm{~cm})$ and the difference was significant. The difference in root length was significantly different from each other at 1 and 2 per cent inoculum density. The root length decreased with increase in the inoculums density however, the reduction in the root length was not significant at different densities from 2 per cent to 5 per cent. The root length recorded at different inoculums densities were in the following order.

\section{Control $>1 \%>2 \%>3 \%>4 \%>5 \%$}

Shoot length was highest at one percent inoculum density $(15.16 \mathrm{~cm})$ i.e., 21.85 per cent reduction over control $(19.40 \mathrm{~cm})$. Least shoot length was recorded at 5 percent inoculum density $(8.33 \mathrm{~cm})$ which is 57.61 per cent reduction over control. Shoot length of groundnut plant gradually decreased with increase of inoculum densities from 1 to 5 per cent (Plate 2). The reduction in shoot length observed at one percent inoculums density is significant compared to control however, the difference in shoot length recorded from 1 per cent to 4 per cent inoculum densities was not significant. The reduction in the shoot length was significant between 4 per cent to 5 per cent inoculum densities. The shoot length recorded at different inoculums densities were in the following order.

Control $>1 \%>2 \%>3 \%>4 \%>5 \%$ 
Table.1 Effect of different inoculum densities of S. rolfsii on seed germination, plant growth parameters and stem rot disease incidence in groundnut

\begin{tabular}{|c|c|c|c|c|c|c|c|}
\hline $\begin{array}{l}\text { Inoculum density } \\
\qquad(\%)\end{array}$ & Germination (\%) & $\begin{array}{c}\text { Per cent } \\
\text { inhibition over } \\
\text { control }\end{array}$ & $\begin{array}{l}\text { Root length } \\
\quad(\mathrm{cm})\end{array}$ & $\begin{array}{c}\text { Per cent } \\
\text { inhibition over } \\
\text { control }\end{array}$ & $\begin{array}{c}\text { Shoot } \\
\text { length }(\mathrm{cm})\end{array}$ & $\begin{array}{c}\text { Per cent } \\
\text { inhibition over } \\
\text { control }\end{array}$ & Symptoms observed \\
\hline 1 & $45.83\left(42.57^{* *}\right)$ & 52.17 & 12.37 & 17.69 & 15.16 & 21.85 & No symptoms \\
\hline 2 & $37.50(37.57)$ & 60.86 & 10.73 & 28.60 & 14.20 & 26.80 & No symptoms \\
\hline 3 & $33.33(35.16)$ & 65.21 & 9.77 & 34.99 & 13.33 & 31.28 & No symptoms \\
\hline 4 & $29.17(32.57)$ & 69.56 & 8.33 & 44.57 & 11.33 & 41.59 & Sclerotia were observed at the base of stem \\
\hline 5 & $16.66(23.79)$ & 82.61 & 7.50 & 50.09 & 8.33 & 57.61 & $\begin{array}{l}\text { Blackening of stem portion and formation } \\
\text { of sclerotia at blackened potion }\end{array}$ \\
\hline Control & $95.83(83.08)$ & & 15.03 & & 19.40 & & \\
\hline C.D. & 12.41 & & 1.24 & & 2.33 & & \\
\hline $\mathrm{SE}(\mathrm{m})$ & 3.98 & & 0.39 & & 0.75 & & \\
\hline $\mathrm{SE}(\mathrm{d})$ & 5.63 & & 0.56 & & 1.06 & & \\
\hline C.V. & 16.25 & & 6.48 & & 9.54 & & \\
\hline
\end{tabular}

Plate.1 Effect of different inoculum densities of S. rolfsii on seed germination and growth of groundnut plants
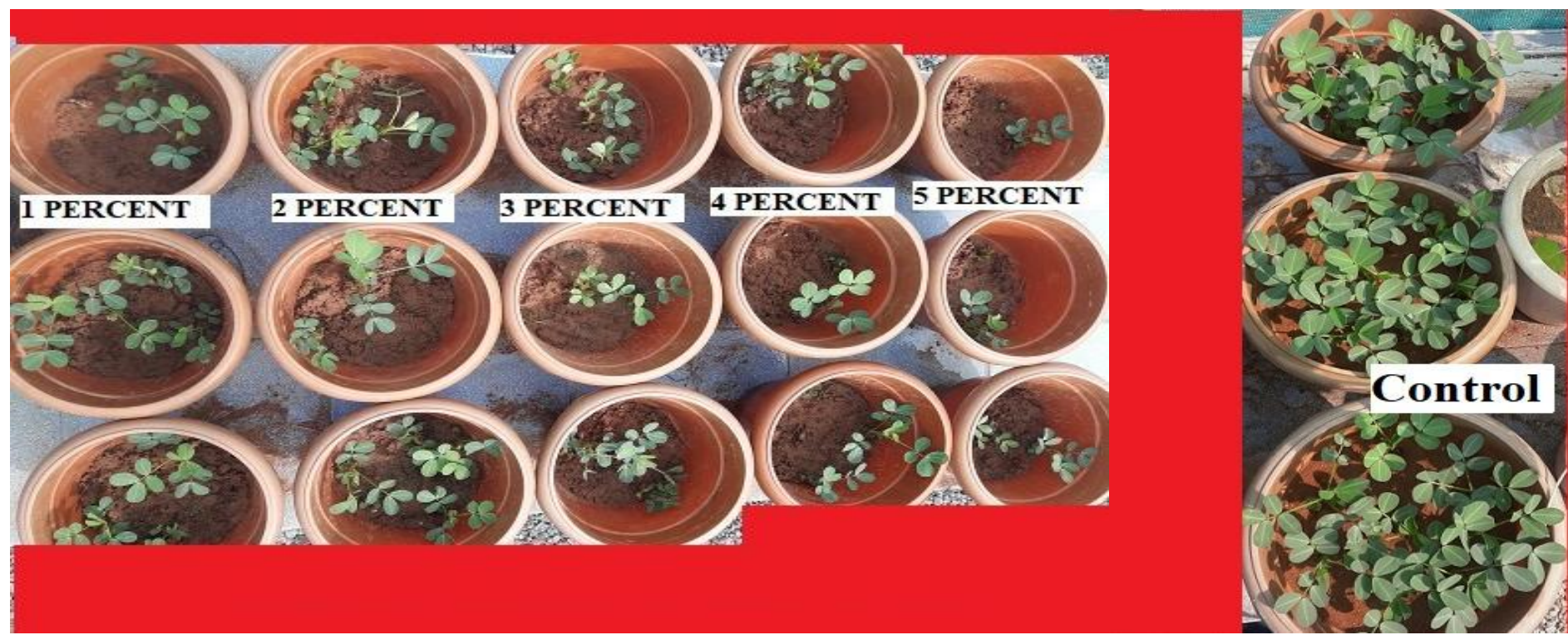
Plate.2 Differences in root and shoot length of groundnut plants at different inoculum densities

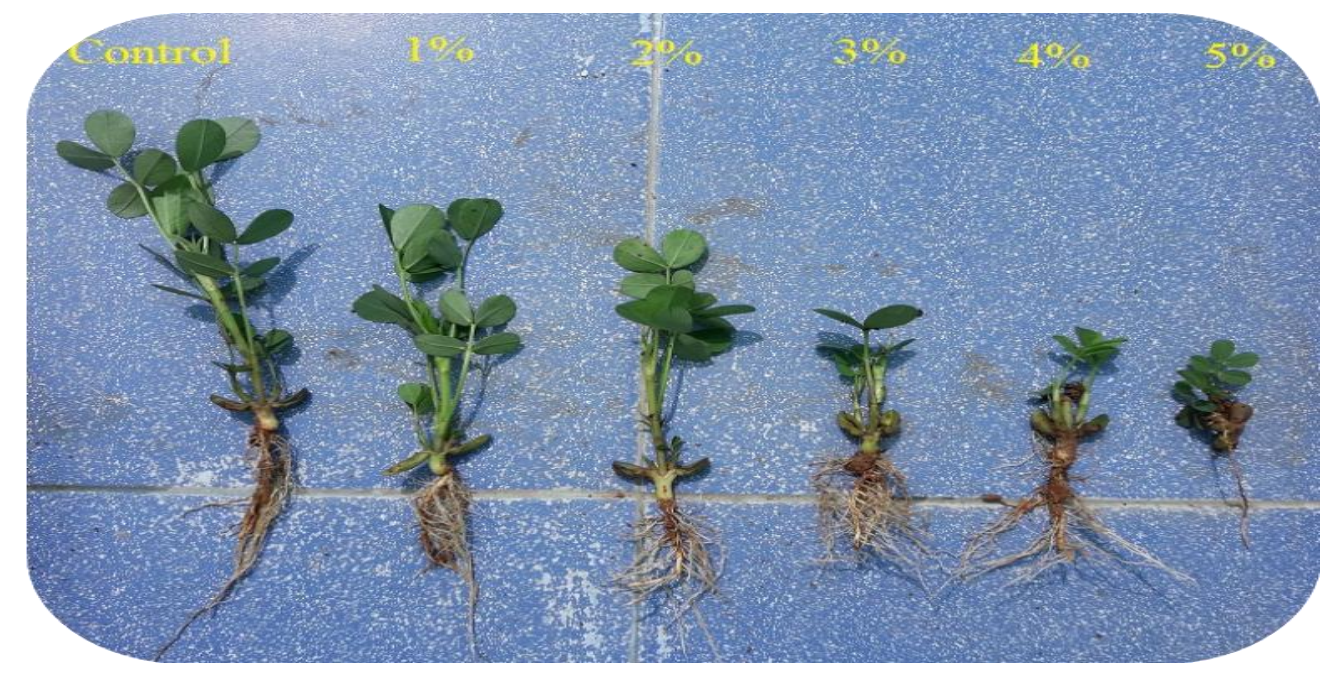

Plate.3 Sclerotial development at 4 and 5 per cent inoculum density

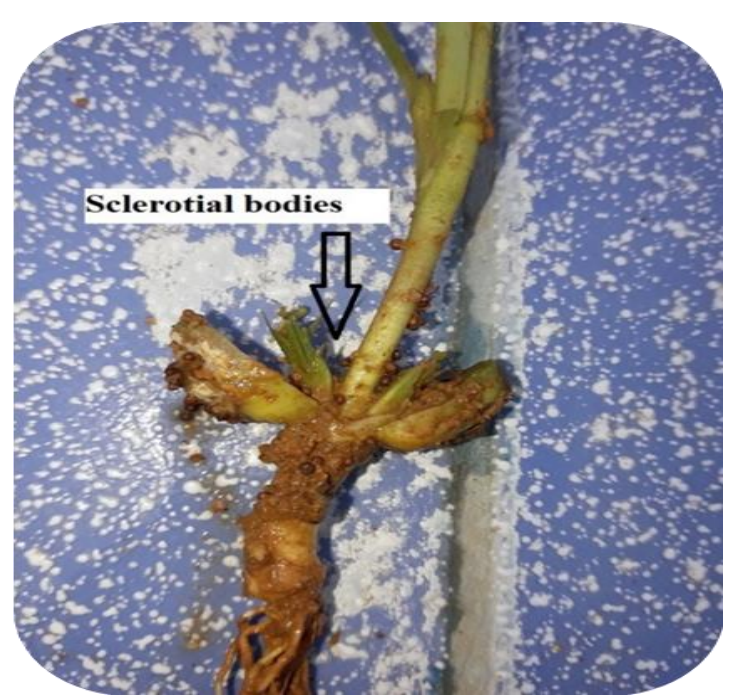

$4 \%$ inoculum

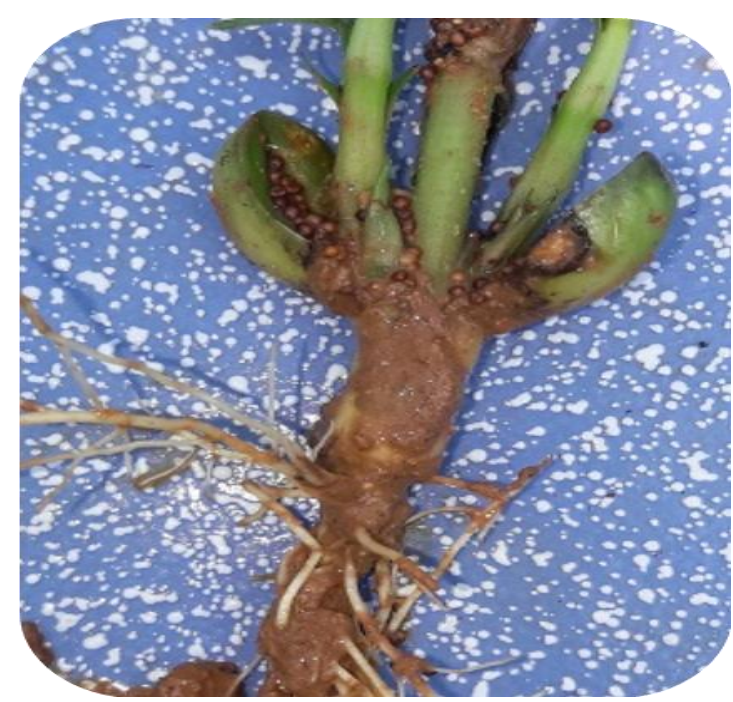

$5 \%$ inoculum 
Fig.1 Effect of different inoculum densities of S. rolfsii on seed germination, plant growth parameters of groundnut

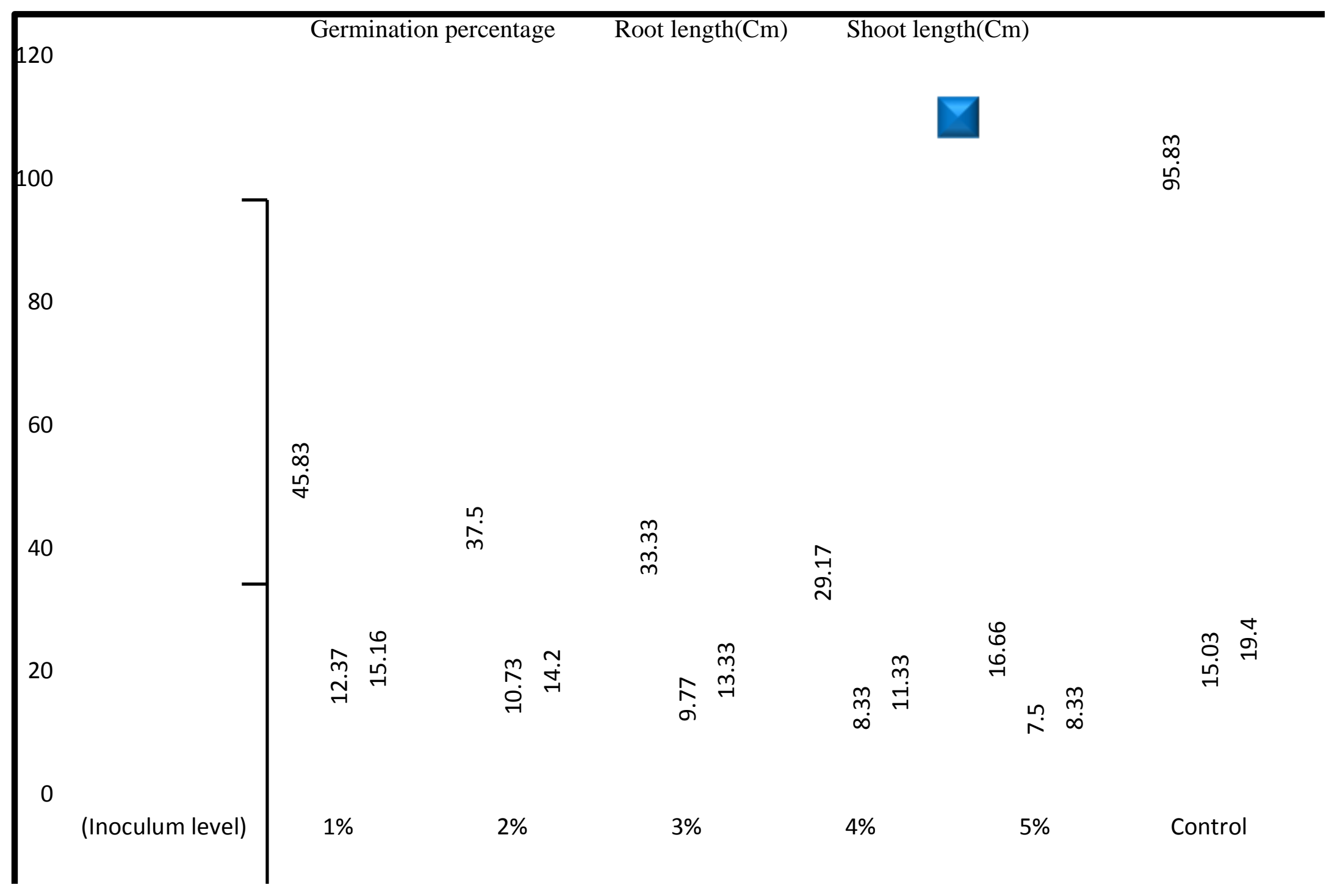


From the above experiment, it is clear that even at one percent inoculum density the germination percentage of groundnut seeds was affected by more than 50 per cent. Hence throughout the experimentation one percent inoculums was applied and also sick soil was maintained by adding one percent inoculum.

Disease symptoms were not observed in any of the treatments at 14 days after sowing. However development of sclerotial bodies were observed at 4 and 5 per cent inoculum (Plate 3). Mc Clain and Scharpf (1989) reported a positive correlation between seedling mortality and inoculum density in coniferous species, whereas plant height and weight of the surviving seedlings were negatively correlated with sclerotial density of Macrophomina phaseolina. Azhar et al., (2006) reported that seedling mortality increased with increase in inoculum levels in collar rot of chickpea. Harlapur (1988) noticed maximum infection $(100 \%)$ in inoculum level of more than four per cent in foot rot disease of wheat.

Germination percentage, root length and shoot length of groundnut was gradually decreased with increase of inoculum levels from 1 to 5 per cent. Lowest germination $(16.66 \%)$, root length $(7.50 \mathrm{~cm})$, shoot length $(8.33 \mathrm{~cm})$ was observed in 5 per cent inoculum levels. Since the germination of groundnut seeds was reduced to more than 50 per cent at one per cent inoculums level, it was followed throughout the investigation.

\section{References}

Aycock, R. 1966. Stem rots and other disease caused by Sclerotium rolfsii. North Carolina Agricultural Experiment Station Technical Bulletin 174: 202.

Azhar, H., Ayub, Md.I.N and Zahid, M.A. 2006 Factors affecting development of collar rot disease in chick pea. Pakistan Journal of Botany. 38 (1): 211-216.

Chet, I. 1975. Ultra structural basis of sclerotial survival in soil. Microbial Ecology. 2:194-200.

Harlapur, S.I. 1988. Studies on some aspects of foot rot of wheat caused by Sclerotium rolfsii Sacc. M. Sc. (Ag), Thesis submitted to University of Agricultural Sciences, Dharwad.

Higgiens, B.B. 1927. Physiology and parasitism of Sclerotium rolfsii (Sacc.). Phytopathology. 17: 417-448.

Khirood, D and Paramjit Kaur, J. 2013. Management of stem rot of groundnut (Arachis hypogaea L.) cultivar in field. Notulae Scientia Biologicae. 5 (3): 316324.

Kilpatrick, R.H and Merkle, O.G. 1967. Seedling disease of wheat caused by Sclerotium rolfsii. Phytopathology. 57: 538-540.

Kumar, N., Dagla, M.C., Ajay, B.C., Jadon, K.S and Thirumalaisamy. 2013. Sclerotium stem rot: A threat to groundnut production. Popular Kheti. 1 (3): 26-30.

Mc Clain, A.I.I and Scharpf, H.F. 1989. Effect of inoculum density of Macrophomina phaseolina on seedling susceptibility of six coniferous species. European Journal of Forest Pathology. 19: 119-123.

Nargund, V.B. 1981. Studies on foot rot of wheat caused by Sclerotiumrolfsii Sacc. in Karnataka. M.Sc. (Ag.) Thesis. University of Agricultural Sciences, Bangalore.

Palakshappa, M.G. 1986. Studies on foot rot of betel vine caused by Sclerotium rolfsii Sacc. in Karnataka. M.Sc. (Ag.) Thesis. University of Agricultural Sciences, Bangalore.

Rodriguez-Kabana, R., Backman, P.A and Williams, J.C. 1975. Determination of yield losses due to Sclerotium rolfsii in 
peanut fields. Plant Disease Reporter. 59: 855-858.

Rolfs, P.H. 1892. The tomato and some of its diseases. Florida University Agricultural Experimental Station Bulletin. 21: 1-38.

Saccardo, P.A. 1911. Notae mycologicae. Annals Mycologici. 9: 249-257.
Uma Singh, P and Thapliyal, P. 1998. Effect of inoculum density, host cultivars and seed treatment on the seed and seedling rot of soybean caused by Sclerotium rolfsii. Indian Phytopathology. 51 (3): 244-246.

\section{How to cite this article:}

Raghavendra, B., T. Srinivas and Padmodaya, B. 2018. Effect of Different Inoculum Densities of $S$. rolfsii on Seed Germination, Seedling Growth Parameters and Disease Incidence. Int.J.Curr.Microbiol.App.Sci. 7(08): 84-91. doi: https://doi.org/10.20546/ijcmas.2018.708.010 